\title{
Problems and Solutions for Women Entrepreneurs in India
}

\author{
Mrs. Shilpika Pandey \\ Assistant Professor, Department of Management \\ Ambalika Institute of Management and Technology, Lucknow
}

\begin{abstract}
The fact is universally accepted that "if a woman grows, along with her grows the family, the society and the nation". But this same family, society and nation act as a roadblock in the development of the status of women. Entrepreneurship is the most promising avenue for being financially and socially independent for the female population. In a developing country like India women constitute around $10 \%$ of total population of entrepreneurs. They have emerged as the rising stars of economies like India to bring wealth and prosperity. But still their valuable contributions are left ignored due to numerous societal and economical barriers. In this fast moving economy the government, NGOs, social scientists and international agencies have been showing interest in social upliftment of women entrepreneurs by initiating development programs and policies. On the other hand the obstacles created by society and women themselves have hindered their growth. Certain behavioral, social, institutional and government measures have been instrumental in empowering women entrepreneurship but their actual impact can be viewed only if these developmental policies are implemented eliminating societal and economic disparities.
\end{abstract}

Keywords: Meaning of women entrepreneur, challenges of Indian women entrepreneurs, factors influencing women entrepreneurship, measures taken by the Indian government

\section{OBJECTIVES AND RESEARCH METHODOLOGY OF THE STUDY}

The study is based on secondary data which is collected from the published reports of RBI, NABARD, Census Surveys, SSI Reports, newspapers, journals, websites, etc.

The study was planned with the following objectives:

- To evaluate the factors responsible for encouraging women to become entrepreneurs

- To critically examine the problems faced by women entrepreneurs.

- To find out status of Indian women entrepreneurs

- To find measures to promote women entrepreneurs

\section{Women Entrepreneurs:}

Women entrepreneurs are highly instrumental in accelerating the economy of a developing country in terms of their contribution. In recent years, even among the developed countries like USA and Canada, Women's role in terms of their share in small business has been increasing. The facts of a study: Conducted by IIT, Delhi are 


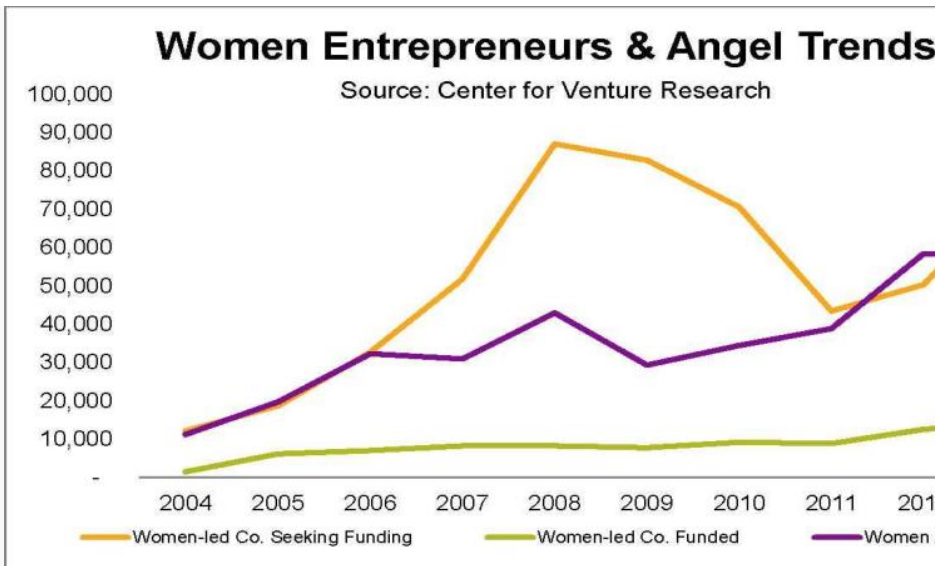

(i) Women own one-third of small business in USA and Canada.

(ii) Britain has seen an increase of over three times of women in workforce than that of men even since 1980s.

(iii) Women make for 40 percent of total work force in Asian Countries.

(iv) In China, women outnumber men by at least two times when it to starting business there.

(iv) In Japan, the percentage of women entrepreneurs increased from 2.4 percent in 1980 to 5.2 percent in 1995 .

(v) In India, women constitute around 48 percent of the population but their participation in the economic activities is only 34 percent. As per the Human Development Report (2007), India ranks 96th on the gender related development index of 137 nations. $T$

\section{RISE OF WOMEN ENTREPRENEURS}

The glass ceilings are shattered and women are found indulged in every line of business. The entry of women into business in India is traced out as an extension of their kitchen activities, mainly $3 \mathrm{P}^{\prime} \mathrm{s}$, Pickle, Powder and Pappad. But with the spread of education and passage of time women started shifting from 3P's to modern 3E's i.e., Energy, Electronics and Engineering. Skill, knowledge and adaptability in business are the main reasons for women to emerge into business ventures. Women Entrepreneur'is a person who accepts challenging role to meet her personal needs and become economically independent. A strong desire to do something positive is an inbuilt quality of entrepreneurial women, who is capable of contributing values in both family and social life. With the advent of media, women are aware of their own traits, rights and also the work situations. The challenges and opportunities provided to the women of digital era are growing rapidly that the job seekers are turning into job creators. Many women start a business due to some traumatic event, such as divorce, discrimination due to pregnancy or the corporate glass ceiling, the health of a family member, or economic reasons such as a layoff. But a new talent pool of women entrepreneurs is forming today, as more women opt to leave corporate world to chart their own destinies. They are flourishing as designers, interior decorators, exporters, publishers, garment manufacturers and still exploring new avenues of economic participation.

\section{PROBLEMS FACED BY WOMEN ENTREPRENEURS:}

\section{Problem of Finance:}

Finance is regarded as "life-blood" for any enterprise, be it big or small. However, women entrepreneurs suffer from shortage of finance on two counts. 
Firstly, women do not generally have property on their names to use them as collateral for obtaining funds from external sources. Thus, their access to the external sources of funds is limited.

Secondly, the banks also consider women less credit-worthy and discourage women borrowers on the belief that they can at any time leave their business. Given such situation, women entrepreneurs are bound to rely on their own savings, if any and loans from friends and relatives who are expectedly meager and negligible. Thus, women enterprises fail due to the shortage of finance.

\section{Scarcity of Raw Material:}

Most of the women enterprises are plagued by the scarcity of raw material and necessary inputs. Added to this are the high prices of raw material, on the one hand, and getting raw material at the minimum of discount, on the other. The failure of many women co-operatives in 1971 engaged in basket-making is an example how the scarcity of raw material sounds the death-knell of enterprises run by women (Gupta and Srinivasan 2009).

\section{Stiff Competition:}

Women entrepreneurs do not have organizational set-up to pump in a lot of money for canvassing and advertisement. Thus, they have to face a stiff competition for marketing their products with both organized sector and their male counterparts. Such a competition ultimately results in the liquidation of women enterprises.

\section{Limited Mobility:}

Unlike men, women mobility in India is highly limited due to various reasons. A single woman asking for room is still looked upon suspicion.
Cumbersome exercise involved in starting an enterprise coupled with the officials humiliating attitude towards women compels them to give up idea of starting an enterprise.

\section{Family Ties:}

In India, it is mainly a women's duty to look after the children and other members of the family. Man plays a secondary role only. In case of married women, she has to strike a fine balance between her business and family. Her total involvement in family leaves little or no energy and time to devote for business.

Support and approval of husbands seem necessary condition for women's entry into business. Accordingly, the educational level and family background of husbands positively influence women's entry into business activities.

\section{Lack of Education:}

In India, around three-fifths $(60 \%)$ of women are still illiterate. Illiteracy is the root cause of socioeconomic problems. Due to the lack of education and that too qualitative education, women are not aware of business, technology and market knowledge. Also, lack of education causes low achievement motivation among women. Thus, lack of education creates one type or other problems for women in the setting up and running of business enterprises.

\section{Male-Dominated Society:}

Male chauvinism is still the order of the day in India. The Constitution of India speaks of equality between sexes. But, in practice, women are looked upon as abla, i.e. weak in all respects. Women suffer from male reservations about a women's role, 
ability and capacity and are treated accordingly. In nutshell, in the male-dominated Indian society, women are not treated equal to men. This, in turn, serves as a barrier to women entry into business.

\section{Low Risk-Bearing Ability:}

Women in India lead a protected life. They are less educated and economically not self-dependent. All these reduce their ability to bear risk involved in running an enterprise. Risk-bearing is an essential requisite of a successful entrepreneur.

\section{SUGGESTIONS FOR THE GROWTH OF WOMEN ENTREPRENEURS}

Right efforts from all areas are required in the development of women entrepreneurs and their greater participation in the entrepreneurial activities. Entrepreneurship basically implies being in control of one's life and activities and women entrepreneurs need to be given confidence, independence, and mobility to come out of their paradoxes. The following measures are suggested to empower the women to seize various opportunities and face challenges in business.

- There should be a continuous attempt to inspire, encourage, motivate and co operate women entrepreneurs.

- An Awareness programme should be conducted on a mass scale with the intention of creating awareness among women about the various areas to conduct business.

- Attempts should be made to enhance the standards of education of women in general as well making effective provisions for their training, practical experience and personality development programmes, to improvise their over-all personality standards.
- Organize training programmes to develop professional skill set in managerial, leadership, marketing, financial, production process, profit planning, maintaining books of accounts and other skills. This will motivate women to undertake business.

- Vocational training to be extended to women community that enables them to understand the production process and production management

- Skill development to be done in women's polytechnics and industrial training institutes. Skills are put to work in trainingcum-production workshops.

- Educational institutes should tie up with various government and non-government agencies to assist in entrepreneurship development mainly to plan business projects.

- International, National, Local trade fairs, Industrial exhibitions, seminars and $v$ conferences should be organized to help women to facilitate interaction with other women entrepreneurs.

- Women in business should be offered soft loans \& subsides for encouraging them into industrial activities.

- The financial institutions should provide more working capital assistance both for small scale venture and large scale ventures.

- Making provision of micro credit system and enterprise credit system to the women entrepreneurs at local level 


\section{CONCLUSION}

It can be said that today we are in a better position wherein women participation in the field of entrepreneurship is increasing at a considerable rate. Efforts are being taken at the economy as brought promise of equality of opportunity in all spheres to the Indian women and laws guaranteed equal rights of participation in political process and equal opportunities and rights in education and employment were enacted. But unfortunately, the government sponsored development activities have benefited only a small section of women i.e. the urban middle class women. Women sector occupies nearly $45 \%$ of the Indian population. At this juncture, effective steps are needed to provide entrepreneurial awareness, orientation and skill development programs to women. The role of Women entrepreneur in economic development is also being recognized and steps are being taken to promote women entrepreneurship. Resurgence of entrepreneurship is the need of the hour emphasizing on educating women strata of population, spreading awareness and consciousness amongst women to outshine in the enterprise field, making them realize their strengths, and important position in the society and the great contribution they can make for their industry as well as the entire economy. Women entrepreneurship must be moulded properly with entrepreneurial traits and skills to meet the changes in trends, challenges global markets and also be competent enough to sustain and strive for excellence in the entrepreneurial arena. If every citizen works with such an attitude towards respecting the important position occupied by women in society and understanding their vital role in the modern business field too, then very soon we can pre-estimate our chances of out beating our own conservative and rigid thought process which is the biggest barrier in our country‘s development process.

We always viewed that a smart woman can pick up a job any day, but if she becomes an entrepreneur she can provide a livelihood to 10 more women at least..!!
Highly educated, technically sound and professionally qualified women should be encouraged for managing their own business, rather than dependent on wage employment outlets. The unexplored talents of young women can be identified, trained and used for various types of industries to increase the productivity in the industrial sector.

\section{REFERENCES}

- Arora, R.;and Sood, S.K.(2005), -Fundamentals of Enterpreneurship and Small Business\| Baporikar, N. (2007)

- Entrepreneurship Development \& Project Management- Himalaya Publication House. Brush, C. (1997). Taori ,Dr. Kamal -

- Entrepreneurship in the Decentralised Sector WomenOwned Businesses: Obstacles and Opportunities, Journal of Developmental

- Entrepreneurship. Desai, V: (1996) Dynamics of Entrepreneurial \& Development \& Management Himalaya publishing House - Fourth Edition, Reprint. ZENITH

- Women Entrepreneurs: Opportunities, Performance and Problems, Deep sPublisher (P) Ltd., New Delhi. Gordon E. \& Natarajan K.: (2007)

- Entrepreneurship Development - Himalaya Publication House, Second Revised edition. Hattangadi Dr. Vidya: (2007)

- Entrepreneurship - Need of the hour, Himalaya Publication House, First edition.

- Opportunities and challenges for women in business, India Together, Online Report, Civil Society Information Exchange Pvt. Ltd.

- WEBSITES 
- info@ijrcm.org.in accessed on 19 April 2011 www. Smallindustryindia.com accessed on 4 April 2011 www.dcmsme.gov.in/schemes/Schemes for the development and promotion of women entrepreneurs.

- PDF accessed on 4 April 2011 www.ghallabhansali.com accessed on 4 April 2011

- www.icfaijournals.com accessed on 4 April 2011

- www.imer.com accessed on 7 April 2011 